\title{
11
}

\section{A Narrative Approach to Exploring Values in Organisations}

\author{
Gry Espedal and Oddgeir Synnes
}

\section{Introduction}

Values in organisations can be difficult to study. Often, the values of an organisation are taken for granted or more or less tacit in various activities and practices. If you ask organisational members what values they think are of importance or what values they themselves practise, they may find it difficult to answer. They often present the organisation's core values or say what they are obliged to say, or they might respond by telling a story.

A well-established definition of values is 'a conception, implicit or explicit, distinctive of an individual or characteristic of a group, of the desirable which influences the selection from available modes, means and ends of action' (Kluckhohn, 1951). Here, values are presented as influencing modes and actions, but how this is done in practice is not highlighted. In this chapter, we will argue that by investigating narratives we

\footnotetext{
G. Espedal $(\bowtie) \bullet$ O. Synnes

VID Specialised University, Oslo, Norway

e-mail: gry.espedal@vid.no; Oddgeir.Synnes@vid.no

(C) The Author(s) 2022

G. Espedal et al. (eds.), Researching Values,

https://doi.org/10.1007/978-3-030-90769-3_11
} 
can deepen and broaden research on values and values in practice. Through stories, we can obtain an in-depth understanding of the connections between institutions, intentions, values and actions.

In organisation theory, narratives are often presented as giving insight into what develops, changes or sustains organisations (Czarniawska, 1997 , p. 24). Boje (1991, p. 106) defines organisations as 'A collective storytelling system in which the performance of stories is a key part of members sense-making'. Sense-making proceeds when participants collectively perform a story as some kind of pattern in organisational practice. Narratives provide a structure in which the past, present and future connect. They can bring forward institutional values that recall and represent the past but also re-interpret the past for present purposes to shape future activities (Linde, 2001). Thus, narratives can play a crucial role in identifying organisational processes that configure temporality as well as organisational identity.

But how do we go about researching values through stories? How do we collect stories? How can we analyse them? And, not least of all, what is a narrative? In this paper, we will give insight into what a narrative is, in which situations narrative analysis can be conveyed and how to analyse narratives when investigating values.

\section{What Is a Narrative?}

So far, we have argued for the centrality of stories to explore values in organisations without specifying what we mean by the concept of story or narrative. The word 'story' shares a common etymology with 'history'. Both words are derived from a group of Greek words that include 'histos', meaning 'web'; 'histanai', meaning 'to stand'; and 'eidenai', meaning 'to know well' (Gabriel, 2000, p. 1). As such, storytelling is about weaving and constructing the product of knowledge. The constructing of knowledge is tied to how stories are linked and actively shaped by a storyteller. The narrative is often used to explain 'a particular way of understanding events' (Cambridge Dictionary, 2021). Narratives are thus not an objective recollection of what happened but an active construction of how the 
different parts are linked together. The sequence of events in a narrative is linked through the story's plot.

Often, the terms 'story' and 'narrative' are used interchangeably. However, a central aspect that is highlighted in the term 'narrative' is connected to the understanding of plot. While a story is an account of incidents or events, a narrative adds a plot or coherence to the story (Boje, 2001). The plot is a way of interpreting and fitting together various episodes through causality. Consider novelist and literary critic E. M. Forster's (1927) well-known example of the difference between the objective events of a story and the ordering of the same events through plot:

'The king died and then the queen died'.

'The king died and then the queen died of grief'.

While the first is a rudimentary story recounting what happened, the second is an example of what Forster calls a plot. Here, two events that are not necessarily linked together (apart from following each other in time) are interpreted and made meaningful through a causal explanation.

This way of thinking of plot as the central aspect of narrative has been hugely influential and has spilled over from literary studies into theories of personal identity and human meaning-making on both an individual and societal level. For instance, in Ricoeur's $(1984,1992)$ theory of narrative identity, it is the plot that gives unity and identity to the character. Our narrative identity is a result of how we interpret various and heterogeneous events throughout life to make sense, or, as Salmon argues, 'Narrative shaping entails imposing a meaningful pattern on what would otherwise be random and disconnected' (Salmon, in Riessman, 2008, p. 5).

\section{When to Use a Narrative Approach}

A narrative approach can be a useful approach in organisational studies where knowledge and experience are not easy to identify. As values often are part of tacit and taken-for-granted knowledge about how organisations organise activities, a narrative approach can be used to identify 
values and value practices. Through narrative research, a researcher's investigation can introduce visibility into leaders' lives and the culture of the organisation, as well as what values leaders/organisations think are valuable. As a researcher, it is also possible to research narratives to identify how cultural expressions and moral interactions between people are enacted and also who the characters of the story are. Finally, you can use a narrative approach to identify how organisational members work on values and practices and what the meaning of values is.

However, there are several critical aspects to be aware of in doing narrative research. As a researcher, you must be observant of the proximity of this type of research to discourse analysis (see Chap. 10). Discourse analysis is more aimed at identifying political, social and critical discussions, while narrative research delves more into the stories themselves and the different voices they represent in an organisation.

As a narrative researcher, you should be observant of your role as a scientist when utilising a narrative approach. Are you ready to take the stories told? Some stories can be sensitive and create difficulties for the informant and also for the researcher. Make sure that there is sufficient support for the informant after you have left if necessary. In utilising a narrative approach, you might also experience that the stories told are not part of the official intentions of the organisation. They might take a critical view of the organisation, and you as a researcher have to take intentions into consideration. As a researcher, you should also be aware that the story is an ongoing construction. It continues after you have left. Not all stories contain every element. You will need to find more than one person's story to identify the pattern. In some situations, you will experience that some individuals are better storytellers than others. Be aware of whether your informants are creating bias in your material.

In addition, if you are concerned with hard, rational facts and a true picture of what is happening, it is not necessarily stories you should ask for. You must be aware that an interpretation takes place in the mind of both the narrator and the listener. 


\section{Narratives and Values}

According to MacIntyre (2007), human actions are entwined with the narratives of the culture: human actions are performed to make specific stories happen. As such, actions, behaviours and practices have underlying meanings related to what is important, desirable and wanted. Hence, narratives are always tied to values of how we choose to interpret actions and situations from our perspective by putting them into a more or less coherent story.

Take the example from Forster of the queen dying of grief, which clearly is a normative version of how a queen ought to react to a king's death. However, maybe her death was not connected to the husband's death. Or maybe it was connected but not as grief. We could easily think of other possible interpretations of why the queen died after the king, depending on the understanding of the two situations. How stories are made intelligible through the ordering of the plot is always value-driven in how it fits the standpoint of the storyteller. Another crucial aspect to understand narrative as connected to values is performativity. Consider Phelan's (1996, p. 218) rhetorical take on narrative as 'somebody telling somebody else on some occasion for some purpose that something happened'. Phelan's conception highlights performativity and context: a story is told at a certain moment in time by a specific narrator to a concrete listener for a reason.

Another important aspect of narrative's close relationship with values is the intertwinement of various types of narrations in which individual stories are played out against larger stories of society and cultures, in opposition or in agreement. The systems we are part of as organisational members are already there, deeply entrenched in our culture and language (Bruner, 1990). Our values are part of the preferences of the culture and, as such, part of the stories we tell of the meaning we use to understand the larger system. In other words, telling stories of what is of worth is part of larger stories of what we value.

Thus, stories are shaped from human life's myriad events and happenings. These are shaped into stories for a particular purpose, to achieve an effect or to bring forward a meaning. What stories thus convey are 
narrative truths, not historical truths (Spence, 1982). A narrative can be contested by other versions, for example, a new version of why the queen died might challenge the established story.

\section{Exploring Values Through Narratives}

Values are beliefs of a particular type. They are 'ideas about the good life' (Morris, 1956), which concern those things 'worth having, doing and being' (Selznick, 1992, p. 60) or what we think is of value. When we as human beings enact our lives, we can be held accountable for that of which we are the authors (MacIntyre, 2007, p. 209). In establishing a link between being an author of life and being held accountable, an opening is made for values as part of the enactment of the story. In authoring ourselves, values become prominent in what we say and especially in what we do.

Narratives can be a central mechanism that provide a bridge between tacit and explicit knowledge, allowing tacit social knowledge of values to be demonstrated and learned (Linde, 2001). The performative aspects of values of what is worth having, doing and being can be explored through narratives revealing how members believe they ought to behave as participants in their unique organisational culture or how they persuasively advocate those values through narratives (Meyer, 1995).

Narratives can also bring forward institutional memories of historical values by recalling and representing the past through invoking and retelling present purposes. Linde (2009) speaks of institutions using narratives in their practice of remembering values. As such, narratives might be seen as a central mechanism that mirrors the values of an organisation's founder (Linde, 2001).

Espedal and Carlsen (2021) have identified a connection between sacred stories and practices in a faith-based organisation. The values work of the organisation is summarised in narratives promoting the value of compassion. One organisational leader said, 'I was at a conference, hearing a young teenager speaking to the audience. He said to the professionals: "You should let your heart take the lead, let it beat as close to the surface as possible, and then let your knowledge follow up" (Espedal \& 
Carlsen, 2021). When back at the workplace, the leader used this story to make a connection to the larger work and the founder of the organisation. She mentioned the encounter with the teenager in meetings with professionals as an example of how they should continuously work on the value of compassion.

Narratives can also be of importance for obtaining information about what is not said. Values in organisations can be both conflicting and counter-active. Counter-narratives can be stories opposing institutional and societal stories (Bamberg \& Andrews, 2004; Frandsen et al., 2016). Stories in organisations can thus display narrative tensions and offer various narrative truths about which values are prominent, given attention and performed in everyday practices.

\section{Narrative Research}

Narrative research is positioned in the field of qualitative research and falls under the scientific tradition of constructionism. Within constructionism, reality is viewed as socially and societally embedded (Grbich, 2012). Knowledge is constructed in the interactions between actors and between the researcher and the researched. Narratives and stories are not fundamentally possessions of the individual; rather, they are products in which individuals render themselves intelligible to others (Gergen \& Gergen, 1988; Hinchman \& Hinchman, 2001). As such, we agree with Nelson (1989), who argues that the researcher does not find narratives but instead participates in their creation.

In conducting narrative research, you might wonder where to find stories. We claim that stories can be found anywhere. For example, as a researcher, you might, in semi-structured interviews, ask for stories. Useful questions and statements to elicit values include the following: Tell me a story of when you made a difference for someone. What do you value most at work? When do you think you are at your best? Tell me why you became a leader. The important aspect of eliciting stories in interviews is letting the interviewer tell the story as fully as possible to develop an understanding of how the narrator tells the event, establishes the settings, includes characters and interprets incidents. 
As a researcher doing observation, you can let stories lead your curiosity. When you write field notes, this can be a collection of stories of what is happening in the organisation. You can use photos, videos and audio recordings to look for stories people tell or values people hold. Archival documents can be used, as well as posts on Instagram and Facebook (this was done by many who were investigating the \#metoo campaign).

Here are some examples of how narratives are used for data gathering in studying values. In a master's thesis at the VID Specialised University, students asked leaders in the middle of the coronavirus crisis to write diaries. They used a solicited diary method, meaning participants were asked to record their actions, thoughts and feelings at the request of the researcher (Alaszewski, 2006). These diaries were stories of the leaders during a crisis situation. In other cases, students have researched stories in appreciation and complaint letters at hospitals. Another student conducted a survey of values in three child welfare institutions for an analysis of storytelling. Stories were collected from the institutions and compared to the official values of the organisations (Jordheim, 2008). Through this approach, it was possible to tell how stories and values were used to make sense in the organisation.

\section{Analysing Narratives Through Three Case Studies}

Once you have the stories, how should you analyse them? There are a few standardised ways of performing narrative analysis. The challenge of using a narrative approach in doing analysis of text is that stories are not generally highly agreed-upon texts, told from beginning to end. They are not static; they vary by the context and implications in which they are told. As such, Boje (2001) describes stories in organisations as selfdeconstructing, flowing, emerging and networking, which provides many approaches to interpretation.

Despite the heterogeneity of stories, in each storytelling there is most often a pattern that models either the past or unfolding and anticipated experiences, intentions and practices. While there are no predefined steps 
for analysing narrative material, it is often common to ask questions that concern the overall (holistic) meaning-making in a story:

- What are the significant events, and how are these ordered through the plot?

- How is the connection between present, past and future interpreted?

- What are the central characters in the stories, and what roles do they play?

- In which settings are the stories played out?

- What different voices are found in the stories? Stories are multi-voiced, displaying tensions between versions of the self, as well as influenced by larger cultural plotlines. See: Frank (2012); Josselson (2011); Riessman (2008); Synnes et al. (2020).

To make clearer how to conduct a narrative approach to analyse narratives and values, we present Riessman's (2008) suggestion of three ways to perform a narrative analysis of written material: (1) thematic analysis: (what is being told and what is the content of the stories?), (2) structural analysis (how is it told, what kind of language is used, metaphors, etc.?) and (3) performative analysis (why is it told, for what purposes?). Within a thematic analysis of narratives, the content is the exclusive focus, and the approach is adapted to uncover and thematically categorise the storytellers and the researchers' experiences. Structural narrative analysis has its roots in the 1970s, when social and organisational scientists took as their methodological position stories, myths, sagas and other forms of narratives as overlooked yet valuable source (Clark, 1972; Mitroff \& Kilmann, 1975; Rhodes \& Brown, 2005). As such, a structural narrative approach might look for the structure of a story to understand how human behaviour and experience are intertwined with available narrative resources. How the story is told, the language used and the metaphors or the coda surfacing in the stories might be analysed (Labov \& Waletzky, 2003). Performative narrative analysis can establish the meaning of why stories are being told in a particular context and for what purposes. Taking a stance in organisational theory, we argue that performative analysis can be of interest when investigating Boje's (1991) perspective of storytelling as sense-making. 
These three analytic perspectives all underscore how narrative analysis is concerned with holistic understanding in which the different parts of a story are seen in light of the pre-figured story or engaged in retrospective sense-making (Boje, 2001). As such, where the researcher puts the emphasis regarding analytic lens might differ from project to project. However, parts of all three narrative approaches are often used in the analysis. We underscore this by presenting three case examples.

We will first turn to one study researching values and value work in a faith-based organisation in Norway (Espedal, 2019). In order to identify how values are part of the ongoing performance of the organisation, a narrative approach was undertaken (Espedal \& Carlsen, 2021). During interviews, a question to elicit narratives was asked: 'Can you tell me a story of when you made a difference to someone at work?' This was done to investigate the practices and stories for which organisational members wished to be known, especially in relation to the core values of compassion and quality. This question was followed by 'How do you know this made a difference to someone?' as a way to gain information on how the informant constructed their knowledge of their story.

In thematically analysing the collected data material, a live coding sequence was utilised (Locke et al., 2015). Through this approach, a list of codes, themes and stories from within-case descriptions were brought to a meeting with the authors. Live coding is a creative process that connects validation and discovery to generate new theories, codes and findings. In the live coding sequence, pattern, content, new stories and inconsistencies in the material were sought to form other creative codes or aggregated dimensions that 'legitimate the new insight' (Locke et al., 2015, p. 374). The thematic live code sequence was used to shift from what actually happened to describe how people make sense of what happened.

In the case study of sacred stories in a faith-based organisation, structural narrative analysis led to a growing recognition of the importance of the meta-stories of the organisation, the tales of the biblical parable of the Good Samaritan and the organisation's founder Maria Haven, as well as the telling of sacred stories in the organisation. Looking across all types of data, including the archives and the observations of patient treatments, the authors singled out 92 excerpts of data that directly or indirectly 
referred to one or all of these stories. The stories were analysed for common structures and basic sequences of exposition, complication and resolution (De Beaugrande \& Colby, 1979; Kintsch, 1978). What the authors found was that the stories had the same plot about not passing by a person in need, whether in relation to marginalised patients or personnel. The authors also scanned through the data for potential contrary narratives and identified 21 excerpts in which people critically contested the grounds of the sacred.

Leaning on a performative analytical perspective, the authors found a repeated practice of telling what they termed 'sacred stories'. The authors drew on prior work to conceive 'sacred' as something within the realm of human ideals and values that people 'set apart' (Anttonen, 2000, p. 42) and grant special significance to as 'inviolable' or 'untouchable' (Harrison et al., 2009, p. 227). The authors explored the meaning of the sacred as a form of values work that extended beyond situations, subjects and organisations (Bednarek-Gilland, 2015) to sources of transcendence (Ricoeur, 1995). Sacred texts (which may be likened to articulations of deeply held values in organisations) were addressed to 'imagination rather than obedience' (Ricoeur, 1977, p. 37). The sacred was latent and realised in performative rather than propositional terms, in events of meaning where people appropriate the possibilities of the text in the situations in which they find themselves (Wallace, 2000).

To understand the performativity of the dynamics of telling and living sacred stories, the researchers turned the stories into two sets of analytical categories: figuring the sacred-as-story and figuring the sacred-as-practice. Through this analytical approach, it was possible to identify how the figuring of the sacred in stories and in actions reinvigorated values work as a two-way, dialectic learning process between the ongoing creative imitation of action and narratives being identified. The study shows that values in the shape of the stories of the sacred do not achieve their meaning as unchangeable cores or sanctioned beliefs. Rather, they come to life in the process of ongoing moral inquiry that co-evolves with moral agencies (Espedal \& Carlsen, 2021).

In a second and well-known study, Polletta (1998) combines elements from Riessman's (2008) analytical perspectives, finding the oral handovers of stories to be of importance in establishing a countrywide civil 
rights protest in the US in the 1960s. It started with a non-violent protest of black students 'sitting in' at a restaurant for white people, symbolising their right to eat in a public place. The demonstration was uncoordinated, but it spread like a fever to other cities, eventually coming to be known as the Greensboro sit-ins.

Polletta shows how narrative analyses are often intertwined with considerations of what people tell, how they tell it and for what purposes. Thematic analyses of campus newspapers; articles, letters and speeches; and organisational and personal correspondence showed a coherent and compelling narrative of the sit-in movement. Structural analysis of the narratives showed the importance of storytelling in constituting the students' activities and their part in the demonstrations. Performative narrative analysis illustrated how the movement led to a sense of urgency, local initiative and moral imperative. The study of the context exposed that the churches were the linchpin of the students' activism, the place for telling stories and supplying leaders and members' guidance, training and inspiration.

In a third study, how stories are closely linked to values was explored in Synnes' research on storytelling among terminally ill cancer patients. The analysis showed how the narrator positioned herself together with significant other characters and in specific meaningful settings, adding weight to the interconnectedness, solicitude and love that had been experienced throughout her life (Synnes, 2012). Another finding was how important nostalgic stories of childhood and youth become when approaching death (Synnes, 2015). Here, the narrative analysis showed how these smaller stories that hardly had been noticed by previous narrative research became important ways of upholding continuity and belonging.

A related perspective from this material argued that the prevalence of stories of childhood homes from the patients must be seen in the light of cultural imaginaries of home, providing legitimacy and substance to the memories (Synnes \& Frank, 2020). Furthermore, the value of the home is not just something that is thematised in the stories but also performed: narrations of home can thus also be ways of home-making. Synnes' research thus shows that values are thematised in stories by, for example, talking about solicitude, love and connectedness. In addition, the analysis 
shows that this telling is also related to available cultural resources and structures (nostalgic stories and cultural imaginaries of home). Finally, the analysis underscores how the telling of these kinds of stories also performs something, makes something happen through the storytelling. Telling a story can thus be seen as narrative care and self-care (Synnes \& Frank, 2020).

\section{Conclusion}

Investigating narratives as a form of sense-making through exploring the plot, and investigating narratives as performative in specific contexts, underscores the close relationship between values and how narratives are central to understanding what matters to people in organisational life. Narrative research can as such be used to explore individual and organisational values that are enacted and authored by organisational members. The narratives provide a structure in which the past, present and future connect. They provide descriptions of sequences of events and can as such be powerful tools for highlighting the ongoing performance of values work and of value practices, telling people what is right and wrong. Narratives unfold at the intersection between discourse and practice and can become a resource that furnishes the embedded agency of the organisational members.

\section{References}

Alaszewski, A. (2006). Using diaries for social research. Sage.

Anttonen, W. (2000). Sacred. In W. Braun \& R. T. McCutcheon (Eds.), Guide to the study of religion (pp. 271-283). Continuum.

Bamberg, M., \& Andrews, M. (2004). Considering counter-narratives: Narrating, resisting, making sense (Vol. Vol. 4). John Benjamins Publishing.

Bednarek-Gilland, A. (2015). Researching values with qualitative methods: Empathy, moral boundaries and the politics of research. Ashgate Publishing Ltd. Boje, D. M. (1991). The storytelling organization: A study of story performance in an office-supply firm. Administrative Science Quarterly, 36(1), 106-126. 
Boje, D. M. (2001). Narrative methods for organizational \& communication research. Sage.

Bruner, J. S. (1990). Acts of meaning. Harvard University Press.

Cambridge Dictionary. (2021). Definition of narrative. https://dictionary.cambridge.org/dictionary/english/narrative

Clark, B. R. (1972). The organizational saga in higher education. Administrative Science Quarterly, 17(2), 178-184.

Czarniawska, B. (1997). Narrating the organization: Dramas of institutional identity. University of Chicago Press.

De Beaugrande, R., \& Colby, B. N. (1979). Narrative models of action and interaction. Cognitive Science, 3(1), 43-66.

Espedal, G. (2019). Being compassionate. Institutionalizing through values work in a faith-based organization. Doctoral dissertation, VID Specialized University, Oslo. https://vid.brage.unit.no/vid-xmlui/handle/11250/2633029

Espedal, G., \& Carlsen, A. (2021). Don't pass them by: Figuring the sacred in organizational values work. Journal of Business Ethics, 169(4), 767-784.

Forster, E. M. (1927). Aspects of the novel. Harcourt.

Frandsen, S., Kuhn, T., \& Lundholt, M. W. (2016). Counter-narratives and organization. Routledge.

Frank, A. W. (2012). Practicing dialogical narrative analysis. In J. A. Holstein \& J. F. Gubrium (Eds.), Varieties of narrative analysis (pp. 33-52). Sage.

Gabriel, Y. (2000). Storytelling in organizations: Facts, fictions, and fantasies. Oxford University Press.

Gergen, K. J., \& Gergen, M. M. (1988). Narrative and the self as relationship. In L. Berkowitz (Ed.), Advances in experimental social psychology (Vol. 21, pp. 17-56). Academic Press.

Grbich, C. (2012). Qualitative data analysis: An introduction. Sage.

Harrison, S. H., Ashforth, B. E., \& Corley, K. G. (2009). Organizational sacralization and sacrilege. Research in Organizational Behavior, 29, 225-254.

Hinchman, L. P., \& Hinchman, S. (2001). Memory, identity, community: The idea of narrative in the human sciences. State University of New York Press.

Jordheim, E. (2008). Hva forteller fortellingene? En kartlegging av verdier $i$ tre barnevernsinstitusjoner gjennom en analyse av historiefortellinger. Master's Thesis in values-based leadership, VID Specialized University, Oslo.

Josselson, R. (2011). Narrative research: Constructing, deconstructing, and reconstructing story. In K. Charmaz \& L. M. McMullen (Eds.), Five ways of doing qualitative analysis: Phenomenological psychology, grounded theory, 
discourse analysis, narrative research, and intuitive inquiry (pp. 224-242). Guilford Press.

Kintsch, W. (1978). On comprehending stories. In M. A. Just \& P. Carpenter (Eds.), Cognitive processes in comprehension (pp. 33-62). Psychology Press.

Kluckhohn, C. (1951). Values and value-orientations in the theory of action: An exploration in definition and classification. In T. Parsons \& E. Shils (Eds.), Toward a general theory of action (pp. 388-433). Harvard University Press.

Labov, W., \& Waletzky, J. (2003). Narrative analysis: Oral versions of personal experience. University of Washington Press.

Linde, C. (2001). Narrative and social tacit knowledge. Journal of knowledge management, 5(2), 160-171.

Linde, C. (2009). Working the past: Narrative and institutional memory. Oxford University Press.

Locke, K., Feldman, M. S., \& Golden-Biddle, K. (2015). Discovery, validation, and live coding. In K. Elsbach \& R. Kramer (Eds.), Handbook of qualitative organizational research: Innovative pathways and methods (pp. 371-380). Routledge, Taylor and Francis Group.

MacIntyre, A. (2007). After virtue (3rd ed.). University of Notre Dame Press.

Meyer, J. C. (1995). Tell me a story: Eliciting organizational values from narratives. Communication Quarterly, 43(2), 210-224.

Mitroff, I. I., \& Kilmann, R. H. (1975). Stories managers tell: A new tool for organizational problem solving. Management Review, 64(7), 18-28.

Morris, C. (1956). Varieties of human value. Chicago University Press.

Nelson, K. (1989). Tales from the crib. Harvard University Press.

Phelan, J. (1996). Narrative as rhetoric: Technique, audiences, ethics, ideology. Ohio State University Press.

Polletta, F. (1998). Contending stories: Narrative in social movements. Qualitative Sociology, 21(4), 419-446.

Rhodes, C., \& Brown, A. D. (2005). Narrative, organizations and research. International Journal of Management Reviews, 7(3), 167-188.

Ricoeur, P. (1977). Toward a Hermeneutic of the Idea of Revelation. Harvard Theological Review, 70(1-2), 1-37.

Ricoeur, P. (1984). Time and narrative. Vol. I. University of Chicago Press.

Ricoeur, P. (1992). Oneself as another. University of Chicago Press.

Ricoeur, P. (1995). Figuring the sacred: Religion, narrative, and imagination. Augsburg Fortress.

Riessman, C. K. (2008). Narrative methods for the human sciences. Sage. 
Selznick, P. (1992). The moral commonwealth: Social theory and the promise of community. University of California Press.

Spence, D. P. (1982). Narrative truth and historical truth: Meaning and interpretation in psychoanalysis. Norton.

Synnes, O. (2012). Forteljing som identitetskonstruksjon ved alvorleg sjukdom: ein hermeneutisk analyse av alvorleg sjuke og doyande sine forteljingar [Narrative as identity construction in serious illness: A hermeneutic analysis of stories of terminally ill patients]. PhD thesis, Norwegian School of Theology, Oslo.

Synnes, O. (2015). Narratives of nostalgia in the face of death: The importance of lighter stories of the past in palliative care. Journal of Aging Studies, 34, 169-176.

Synnes, O., \& Frank, A. W. (2020). Home as cultural imaginary at the end of life. In B. Pasveer, O. Synnes, \& I. Moser (Eds.), Ways of home making in care for later life (pp. 19-40). Palgrave Macmillan.

Synnes, O., Orøy, A. J., Råheim, M., Bachmann, L., Ekra, E. M. R., Gjengedal, E., \& Lykkeslet, E. (2020). Finding ways to carry on: Stories of vulnerability in chronic illness. International Journal of Qualitative Studies on Health and Well-Being, 15(1), 1-12. https://doi.org/10.1080/17482631.2020.1819635

Wallace, M. I. (2000). From phenomenology to scripture? Paul Ricoeur's hermeneutical philosophy of religion. Modern Theology, 16(3), 301-313.

Open Access This chapter is licensed under the terms of the Creative Commons Attribution 4.0 International License (http://creativecommons.org/licenses/ by/4.0/), which permits use, sharing, adaptation, distribution and reproduction in any medium or format, as long as you give appropriate credit to the original author(s) and the source, provide a link to the Creative Commons licence and indicate if changes were made.

The images or other third party material in this chapter are included in the chapter's Creative Commons licence, unless indicated otherwise in a credit line to the material. If material is not included in the chapter's Creative Commons licence and your intended use is not permitted by statutory regulation or exceeds the permitted use, you will need to obtain permission directly from the copyright holder. 